\title{
The relationship between the social responsibility and the job performance among physical education professors
}

\author{
Kenioua Mouloud ${ }^{\mathrm{ABCDE}}$, Krine Nawal ${ }^{\mathrm{DE}}$ \\ University of Ouargla, Algeria
}

Authors' contributions: A - Study design; B - Data collection; C - Statistical analysis; D - Manuscript Preparation; E - Funds Collection.

\begin{abstract}
Purpose: $\quad$ The study aimed to know the level of social responsibility and job performance among the physical education professors and examine the relationship between the social responsibility and the job performance.

Material: $\quad$ The participants were 29 physical educations professors (male) from Institute of Physical Education and Sport University of Ouargla. The social responsibility and the job performance scales were used as search tools. Data analyses were carried out by means of statistical packet for social sciences (SPSS) 26.00 software program. The Mean, Std. Deviation and Pearson Correlation were used in the main study. In addition, alpha-Cronbach was used in the exploratory study.

Results: $\quad$ The level of social responsibility and job performance is high among physical education professors, and there is a positive correlation between social responsibility and job performance.

Conclusions: $\quad$ Given the importance of the role of social responsibility and job performance and the lack of enough studies in this specialization, it is necessary to conduct more additional studies that would serve knowledge in this specialization.

Keywords: $\quad$ social responsibility, job performance, physical education, professors.
\end{abstract}

\section{Introduction}

Social responsibility is considered an important topic in any society, as it relates to the task of defining and controlling the behaviour of individuals within the community [1]. Social responsibility is the commitment of individuals to their actions and behaviours towards society through participation in a range of social activities related to community service [2]. It's associated with many concepts, including those rights, duties, identity, ethics, mission, job and individual and collective conscience [3].

Job performance can be defined on a micro level as actions and behaviour of an employee that contribute to the goals of the organization $[4,5]$. The behaviour aspect refers to what individuals do while at work [4]. Other aspect is the outcome that refers to the results of the individual's behaviour [6].

The teaching staff at the University is considered one of the pillars of the University. It plays a major role in influencing the student's personality and scientific formation. But it does not limited to that role only. It contributes scientifically through scientific discoveries. Intellectual creativity and enrichment of human knowledge and its development are also address to the problem solving of society $[1,7,8]$.

At the University teaching staff has both vital role and high volume of responsibility for the work they do.

It became necessary to study social responsibility, performance and its importance in the character of the professor.

There was the lack of studies on social responsibility and job performance for teaching staff at the University

(c) Kenioua Mouloud, Krine Nawal, 2020

doi:10.15561/26649837.2020.0408 (based on some academic platforms). An exception is the study of Bakar [1]. These make the problem more important.

The aim of this study is to know the level social responsibility and job performance among physical education professors, to investigate relationship between social responsibility and job performance. For the purpose of this study, the research study hypotheses were as follows:

HYP.1 There is high level of social responsibility among physical education professors.

HYP.2 There is high level of job performance among physical education professors.

HYP.3 There is (positive) correlation relationship between social responsibility and job performance among physical education professors.

\section{Material and methods}

Participants. The participants were 29 physical educations professors (male) from Institute of Physical Education and Sport University of Ouargla. The social responsibility and the job performance scales were used as search tools.

Instruments. In this study, two scales were used to collect data. The first scale is social responsibility was prepared by Bakar [1], the scale was distributed according to the Likert type scale. Cronbach alpha reliability value of the scale was found (0.85). The second scale is job performance was prepared by Bakar [1], the scale was distributed according to the Likert type scale. Cronbach alpha reliability value of the scale was done (0.80).

Statistical Analysis. Data analyses were carried out by means of statistical packet for social sciences (SPSS) 
26.00 software program. The Mean, Std. Deviation and Pearson Correlation were used in the main study. In addition, alpha-Cronbach was used in the exploratory study.

\section{Results}

Level of social responsibility among physical education professors

In Table 1, it was found:

- the highest arithmetic mean of social responsibility scale was estimated at $(\mathrm{M}=3.00)$ at standard deviation $(\mathrm{SD}=.000)$;

- the lowest arithmetic mean of social responsibility scale was $(\mathrm{M}=1.82)$ at standard deviation $(\mathrm{SD}=.722)$;

- the value of the total arithmetic mean of the social responsibility scale was estimated at $(\mathrm{M}=2.58)$ with a standard deviation of (SD.192).

It shows that the level of social responsibility is high among physical education professors.

Level of job performance among physical education professors

In Table 2, it was found:

- the highest arithmetic mean of job performance scale was estimated at $(\mathrm{M}=2.96)$ at standard deviation $(\mathrm{SD}=.188)$;

- the lowest arithmetic mean of job performance scale was $(\mathrm{M}=1.96)$ at standard deviation $(\mathrm{SD}=.506)$;

- the value of the total arithmetic mean of the job performance scale was estimated at $(\mathrm{M}=269)$ with a standard deviation of (SD.240);

It shows that the level of job performance is high among physical education professors.

The relationship between social responsibility and job performance among physical education professors.

Table 3 shows:

- there is a positive correlation between social responsibility and job performance among physical education professors;

- the value of the correlation coefficient Pearson was $(0.65)$ at the level of significance $(0.01)$;

It means that the greater the awareness of the concept of social responsibility, the more sense of job performance.

\section{Discussion}

The level of social responsibility is high for physical education professors. The reason perhaps is that they represent a class of a high degree of awareness.

As well as knowing the importance of the large role assigned to them. The professor has a great social responsibility towards students, the University and society [7]. The true social responsibility of the professor is in two dimensions, the internal dimension that depends

Table 1. Shows the results of the means and standard deviations of the social responsibility scale

\begin{tabular}{|c|c|c|c|c|c|}
\hline Items & $\mathrm{N}$ & Mean & SD & Rank & Level \\
\hline 1- I am trying to be in solidarity with members of my residential area & 29 & 2.42 & 741. & 9 & High \\
\hline 2-I maintain my workplace reputation (Sports Institute) & 29 & 2.89 & 416. & 4 & High \\
\hline 3- I try to be honest with myself & 29 & 2.89 & 314. & 4 & High \\
\hline 4- I am ready to offer suggestions to solve my country's problems & 29 & 2.60 & 566. & 7 & High \\
\hline 5- I am working to educate my family (Awareness) & 29 & 2.96 & .188 & 2 & High \\
\hline 6-I feel my moral responsibility to my professors' colleagues & 29 & 2.89 & .314 & 4 & High \\
\hline 7-I am ready to assume any duty to serve the country & 29 & 2.57 & 572. & 8 & High \\
\hline 8- I treat my neighbours well & 29 & 3.00 & .000 & 1 & High \\
\hline 9- I believe that community development is everyone's responsibility & 29 & 2.92 & .262 & 3 & High \\
\hline 10- I assign some of my rights for the happiness of my family & 29 & 2.75 & 440. & 5 & High \\
\hline $\begin{array}{l}\text { 11- I am trying to keep the relationships between my family } \\
\text { members together }\end{array}$ & 29 & 3.00 & .000 & 1 & High \\
\hline $\begin{array}{l}\text { 12- The omission of the constant monitoring of students makes them } \\
\text { neglect their duties }\end{array}$ & 29 & 2.07 & .604 & 11 & Average \\
\hline 13- I control my emotions in tense situations & 29 & 2.39 & 566. & 10 & High \\
\hline 14- I prefer to discuss the problems of my community collectively & 29 & 2.07 & .766 & 11 & Average \\
\hline $\begin{array}{l}\text { 15- I respect the ideas of others even if they contradict my point of } \\
\text { view }\end{array}$ & 29 & 2.60 & .497 & 7 & High \\
\hline 16- I am ready to be a paramedic to save accident victims & 29 & 2.60 & .566 & 7 & High \\
\hline 17- I accept the advice of my friends, with open arms & 29 & 2.64 & .558 & 6 & High \\
\hline $\begin{array}{l}\text { 18- It is difficult for me to adhere to my community's customs and } \\
\text { traditions }\end{array}$ & 29 & 1.82 & .722 & 13 & High \\
\hline $\begin{array}{l}\text { 19- I have fallen into silence if there is a dispute between my } \\
\text { professors' colleagues, even though I can resolve the dispute }\end{array}$ & 29 & 1.85 & .705 & 12 & High \\
\hline 20- I am interested in constantly developing my self & 29 & 2.75 & .585 & 5 & High \\
\hline Total & 29 & 2.58 & 192. & & High \\
\hline
\end{tabular}


Table 2. Shows the results of the means and standard deviations of the job performance scale

\begin{tabular}{|c|c|c|c|c|c|}
\hline Items & $\mathbf{N}$ & Mean & SD & Rank & Level \\
\hline 1- I make sure to carry out my scientific duties & 29 & 2.82 & .390 & 5 & High \\
\hline 2- I employ modern technology in conference hall & 29 & 2.53 & 637 & 10 & High \\
\hline $\begin{array}{l}\text { 3- I make sure to diversify teaching methods to attract student } \\
\text { attention }\end{array}$ & 29 & 2.71 & .460 & 7 & High \\
\hline 4- I make sure to keep up with university activities and laws & 29 & 2.71 & .534 & 7 & High \\
\hline 5- I am working to make the student the hub in the classroom & 29 & 2.75 & .518 & 6 & High \\
\hline 6- I use the blackboard to clarify the concepts of the lesson & 29 & 2.60 & .628 & 9 & High \\
\hline 7-I rely on my teaching on the elements of excitement and suspense & 29 & 2.75 & .440 & 6 & High \\
\hline 8- I can develop my scientific area & 29 & 2.92 & .262 & 2 & High \\
\hline $\begin{array}{l}\text { 9- Lessons added on the quorum do not affect my scientific } \\
\text { attribution }\end{array}$ & 29 & 2.00 & 544. & 12 & Average \\
\hline $10-I$ use technical means that contribute to clarifying the lesson & 29 & 2.71 & .460 & 7 & High \\
\hline 11- I always have the desire to teach in all times & 29 & 1.96 & .507 & 13 & Average \\
\hline 12- Working with my students gives me happiness & 29 & 2.85 & .356 & 4 & High \\
\hline $\begin{array}{l}\text { 13- I set organized times to meet my students and solve their } \\
\text { problems }\end{array}$ & 29 & 2.42 & 643 & 11 & High \\
\hline $\begin{array}{l}\text { 14-When I am late for my lesson, I feel a sense of embarrassment } \\
\text { toward my students }\end{array}$ & 29 & 2.71 & .599 & 7 & High \\
\hline 15- I encourage my students to interact with each other & 29 & 2.89 & 314. & 3 & High \\
\hline 16- I feel comfortable when I help my students & 29 & 2.85 & .356 & 4 & High \\
\hline 17- I stay away from situations that lead to waste of time & 29 & 2.67 & .475 & 8 & High \\
\hline 18- I deal with my students in a good way & 29 & 2.89 & .314 & 3 & High \\
\hline 19- I distribute my interest to all students & 29 & 2.92 & .262 & 2 & High \\
\hline 20- My relationship with students is based on affection and love & 29 & 2.96 & .188 & 1 & High \\
\hline 21- I develop positive trends for students & 29 & 2.85 & .356 & 4 & High \\
\hline Total & 29 & 2.69 & .240 & & High \\
\hline
\end{tabular}

Table 3. Shows the Pearson correlation coefficient between the scales of social responsibility and job performance

\begin{tabular}{llll}
\hline \multirow{2}{*}{$\begin{array}{l}\text { Social responsibility } \\
\text { job performance }\end{array}$} & $\mathbf{N}$ & Correlation coefficient & Significance level \\
\cline { 2 - 4 } & 29 & 0.65 & 0.01 \\
\hline
\end{tabular}

on the moral values of society, and the external dimension that depends on contemporary international variables [9]. Solving students' educational and social problems is part of the professor's social responsibility [10-12]. The professor is the pillar in the University education system in research, education, service to society and participation in the comprehensive development [13].

The level of the job of performance is high for physical education professors. The reason is due to the availability of an appropriate organizational climate for work, good relationship with everyone.These motivate them to fulfil their roles in the best way and harness all their energies for the success of academic and social tasks.

This result agreed with the results of Souam [14], Arabiyat [15] and Al-yahya [16]. Nassar's [17] study indicates that the level of teaching performance is great among professors and the highest level is preparation and planning for the lesson, then dialogue and discussion with students, then evaluation and measurement, and finally scientific research. Nagy [18] refers that faculty members in academic departments and faculties are doing their best to advance their university and maintaining their distinguished scientific level despite the difficult conditions that hinder them.

There is a positive correlation with a positive statistical significance between social responsibility and job performance for physical education professors. Hence the professor revitalizes the sporting activities of associations and clubs. Such organizations take care of specific groups such as orphans, people with special needs, necessarily. In this case the professor is a persistent professor who performs his job proficiently at the university. Also, a professor who respects his working hours and attends on time and provides lessons and lectures professionally. He offers community work. He becomes role models. Thus students imitate him not only in the Institute/Faculty but even in their private lives. This result agreed with the results of Bakar [1]. The study of Al-Hilali and Al- 
Sherbini [19] indicates that competent faculty members have a spirit of social responsibility. An individual's commitment to his work and duties is a kind of social responsibility [20]. A strong sense of social responsibility will increase the level of job performance [21].

\section{Conclusion}

Through theoretical and applied study of the topic became clear that social responsibility and job performance were high. There was also a positive correlation between the two variables. Given the importance of the role of social responsibility and job performance and the lack of enough studies in this specialization, it is necessary to conduct more additional studies that would serve knowledge in this specialization.

\section{Conflict of interest}

The authors declare that there is no conflict of interest.

13.Bouab R. The social and functional performance of the university professor in the LMD system. Social and Human Sciences Journal, 2015;21:71-86.

14.Souam R. The empowerment as a strategic approach to achieving excellence in performance among faculty members from the viewpoint of department heads. Studies Journal. 2012; 50: 11-33. https://doi.org/10.1002/pfi.20248

15.Arabiyat B. The patterns of educational leadership prevailing among the heads of academic departments at Al-Balqa Applied University and their impact on the job performance of faculty members. Islamic University Journal for Educational and Psychological Studies. 2012; 20: 705-736.

16.Al-yahya S. Standards of personal quality performance among department heads and methods of enhancing them in Saudi universities. Jordanian Journal of Educational Sciences. 2011; 7: 35-58.

17.Nassar ACH. The reality of the teaching performance of faculty members in colleges of education from the viewpoint of students in the universities of Gaza. Journal of the Islamic University of Studies. 2017; 25: 160-174. https://doi.org/10.12816/0035834

18. Nagy RS. The degree of practice of heads of academic departments at Al-Aqsa University for Excellence Management is related to the level of improvement in the performance of faculty members. Arab Journal for Quality Assurance of University Education. 2018; 35:123-135. https://doi.org/10.20428/AJQAHE.11.35.6

19.Al-Hilali GH, Al-Sherbini A. Entrance to Excellence Management and its application requirements at Mansoura University. The Future of Arab Education. 2013; 83: 11-142.

20.Abdul Hassan R. Citizenship and its relationship to social responsibility. Educational and Psychological Research Journal. 2017; 52: 619-647.

21.Talal BAE. Relationship building moral ethical responsibility among University students. London's second international conference in social science and humanities in the Islamic world research. 2013. P. 100-115. 
Information about the authors:

Kenioua Mouloud; (Corresponding Author); http://orcid.org/0000-0002-5405-5723; moukenioua@gmail.com; Institute of Physical Education and Sport University of Ouargla Algeria.

Krine Nawal; http://orcid.org/0000-0002-4593-7767; nawal_krine18@yahoo.com; Faculty of Literature and Language University of Ouargla, Algeria.

Cite this article as:

Kenioua Mouloud, Krine Nawal. The relationship between the social responsibility and the job performance among physical education professors. Pedagogy of physical culture and sports, 2020;24(4):203-207.

https://doi.org/10.15561/26649837.2020.0408

This is an Open Access article distributed under the terms of the Creative Commons Attribution License, which permits unrestricted use, distribution, and reproduction in any medium, provided the original work is properly cited

(http://creativecommons.org/licenses/by/4.0/deed.en).

Received: 10.01.2020

Accepted: 11.02.2020; Published: 30.08 .2020 